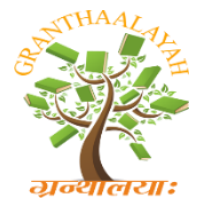

\author{
INTERNATIONAL JOURNAL OF RESEARCH - \\ GRANTHAALAYAH \\ A knowledge Repository
}

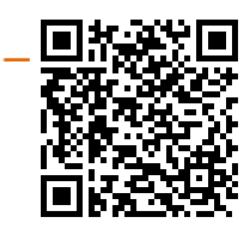

Science

\title{
DYNAMICS OF ROOT AND TUBER CROPS ACREAGE ALLOCATION AND YIELD ADJUSTMENT IN NIGERIA
}

\author{
M. S. Sadiq ${ }^{1}$, N. Karunakaran ${ }^{* 2}$ and I. P. Singh ${ }^{3}$ \\ ${ }^{1}$ Department of Agricultural Economics and Extension Technology, FUT, Minna, Nigeria \\ ${ }^{2}$ Department of Economics, EKNM Government College Elerithattu, Kerala, India \\ ${ }^{3}$ Department of Agricultural Economics, SKRAU, Bikaner, India
}

\begin{abstract}
This paper empirically studied the growth pattern and supply response of root and tuber crops farmers in Nigeria using annual time series data sourced from FAO database. The data spanned from 1961-2014 and covered area, yield and price of yam, cassava and potatoes crops. The data were analyzed using the growth model, instability index, production decomposition analysis model and Engel-Granger two-step model. Findings showed that area was responsible for the paradigm shift in the production of selected root and tuber crops in Nigeria and not productivity which is very essential for sustainable agriculture due to shrinking of land resource owing to competing demand for its use as evidenced by incessant attacks of herdsmen on arable crop farmers. Generally, the farmers respond to price incentives in reallocating their area and adjusting their yield for all the selected crops. It was also observed that acreage and yield for all the selected crops had long-run association with the price and non-price factors; likewise, it established long-run equilibrium. So the need for price forecast mechanism to checkmate cob-web cycle which affects the balance between supply and demand for the root and tuber crops in the country and increase in production of crops achieved by increasing productivity of land-combination of technology and efficiency in the utilization of resources is recommended.
\end{abstract}

Keywords: Acreage; Yield; Dynamics; Farmers response; Root and tuber crops; Nigeria.

Cite This Article: M. S. Sadiq, N. Karunakaran and I. P. Singh. (2019). "DYNAMICS OF ROOT AND TUBER CROPS ACREAGE ALLOCATION AND YIELD ADJUSTMENT IN NIGERIA." International Journal of Research - Granthaalayah, 7(2), 144-161. https:// doi.org/10.29121/granthaalayah.v7.i2.2019.1016.

\section{Introduction}

The acreage response of agricultural crop is one of the important tools used for predicting the crop production. Agriculture is the most important sector in the economy of any nation. In Nigeria, the geometric rise in its population during the last two decades has been more pronounced than the agricultural production whose rise is marred by a staggering arithmetic growth, creating a lag in the availability and requirement of food crops. 
The impact of any policy reforms on economic growth and poverty alleviation crucially depends on the response of agricultural supply to incentives. In order to make an assessment of the effects and impacts of policies on agricultural growth, farmers' response towards prices and non-price variables is very important. Despite their relevancy, the extent of the supply response of the root and tuber crops farmers in Nigeria to price incentives and non-price factors is still largely unknown. Therefore, it is a matter of paramount importance to study the behavior of the farmer's attitude towards area allocation and yield adjustment to different crops. However, research focused on the root and tuber crops which have assumed the position of a cash crop. The selection of root and tuber crops was premised on the lurking tendency of root and tuber crops food insecurity in the country due to temptation for profit abroad, tendency of market break at home and the tendency of endangering the biodiversity in the country. In addition, the area (land) factor which is responsible for the increase in the production of these crops is facing stiff competition owing to high demand for its use as evidenced by the incessant Fulani herdsmen attack on the arable crop farmers in the country, thus, wreaking havoc on lives and properties. It is against this background that this research was conceived to work out modalities that will ensure sustainable productivity of these crops in the country. The broad objective of this study is to determine how price and nonprice factors governed farmers' decision on the supply of root and tuber crops in the country. The specific objectives were to determine the growth pattern of the selected crops; to determine the instability status of the selected crops; to identify the sources of change in the output of the selected crops; and to determine the impact and effect of the price and non-price factors on the supply response behavior of the selected crop farmers in the country.

\section{Materials and Methods}

The study used annual time series data which spanned across 1961-2014; covering area, yield and prices of yam, cassava and potatoes crop. The data source is the FAO database and the collected data were analyzed using the growth model, instability index, production decomposition analysis model and Engel-Granger two-step procedure model. For a detailed analysis of the growth trend and instability the data were categorized based on the reform periods witnessed in the country: Pre-Structural Adjustment Period (SAP) (1961-1984), SAP (1985-1999) and post-SAP (20002014).

\subsection{Growth Rate}

The compound annual growth rate calculated using the exponential model is given below:

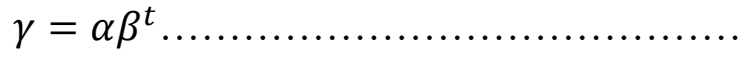

$$
\begin{aligned}
& \ln \gamma=\ln \alpha+t \ln \beta \ldots \ldots \ldots \ldots \ldots \ldots \ldots \\
& C A G R=[\text { Antilog } \beta-1] \times 100 \ldots \ldots \ldots \ldots
\end{aligned}
$$

Where, CAGR is compound growth rate; $\mathrm{t}$ is time period in year; $\gamma$ is area/yield/production; $\alpha$ is intercept; and, $\beta$ is the estimated parameter coefficient. 


\subsection{Instability Index}

The simple coefficient of variation (CV) overestimates the level of instability in time series data characterized by long-term trends, whereas the Cuddy-Della Valle Index corrects the coefficient of variation by instability index which is given below:

$\mathrm{II}=\mathrm{CV}^{*}\left(1-\mathrm{R}^{2}\right)^{0.5}$

Where, II is the instability index; CV is the coefficient of variation; and, R2 is coefficient of multiple determination. In conformity with Dharke and Sharma (2009); and Debnath, et al (2015) the instability index was classified as low instability $(\leq 15 \%)$ and high instability $(>15 \%)$.

\subsection{Decomposition Analysis}

Following Sandeep, et al (2016) the decomposition analysis model used to measure the relative contribution of area and yield to the total output change is given below:

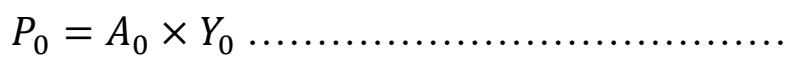

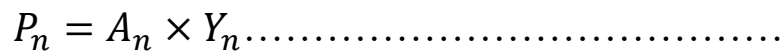

Where, $\mathrm{P}, \mathrm{A}$ and $\mathrm{Y}$ represents the production, area and yield respectively. The subscript 0 and $\mathrm{n}$ represents the base and the nth years respectively

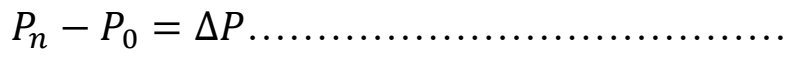

$A_{n}-A_{0}=\Delta A$

$Y_{n}-Y_{0}=\Delta Y$

From equation (5) and (9):

$P_{0}+\Delta P=\left(A_{0}+\Delta A\right)\left(Y_{0}+\Delta Y\right)$

Therefore,

$$
\begin{gathered}
P=\frac{Y_{0} \Delta A}{\Delta P} \times 100+\frac{A_{0} \Delta Y}{\Delta P} \times 100+\frac{\Delta A \Delta Y}{\Delta P} \times 100 \\
\text { Production }=\text { Area effect }+ \text { Yield effect }+ \text { Interaction effect }
\end{gathered}
$$

\subsection{Augmented Dickey Fuller Test}

Following Blay, et al (2015), Singh, et al (2016) and Sadiq, et al (2016) the Augmented DickeyFuller test (ADF) used is given below:

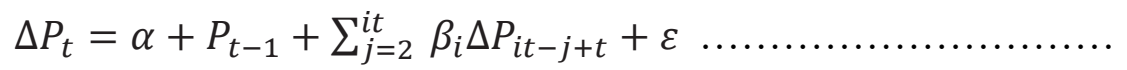


Where, $P_{i t}$ is the $i^{t h}$ crop at the time $t, \Delta P_{i t}\left(P_{i t}-P_{t-1}\right)$ and $\alpha$ is the intercept or trend term.

\subsection{Engel-Granger Two Step Procedure Model}

\subsubsection{Long-Run Dynamic Model}

$Y_{t}=\beta_{0}+\beta_{1} Y_{t-1}+\beta_{2} Y_{2 t-1}+\beta_{3} P_{t-1}+\beta_{4} P_{2 t-1}+\beta_{5} P R_{t-1}+\beta_{6} P R_{2 t-1}+\beta_{7} Y R_{t-1}+$

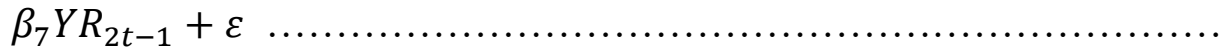

\subsubsection{Short-Run Dynamic Model}

$\Delta Y_{t}=\beta_{0}+\beta_{1} \Delta Y_{t-1}+\beta_{2} \Delta Y_{2 t-1}+\beta_{3} \Delta P_{t-1}+\beta_{4} \Delta P_{2 t-1}+\beta_{5} \Delta P R_{t-1}+\beta_{6} \Delta P R_{2 t-1}+$ $\beta_{7} \Delta Y R_{t-1}+\beta_{7} \Delta Y R_{2 t-1}+\varepsilon$

Where, $Y_{t}$ is the current area/yield at time $\mathrm{t}$ for $\mathrm{i}^{\text {th }}$ crop; $Y_{t-1}$ is the one year lagged area/yield of $\mathrm{i}^{\text {th }}$ crop; $Y_{2 t-1}$ is the one year lagged area/yield of competing crop; $P_{t-1}$ is the one year lagged price of $i^{\text {th }}$ crop; $P_{2 t-1}$ is the one year lagged price of competing crop; $P R_{t-1}$ is the one year lagged price risk of $i^{\text {th }}$ crop measured by the standard deviation of two preceding years; $P R_{2 t-1}$ is the one year lagged price risk of competing crop measured by the standard deviation of two preceding years; $Y R_{t-1}$ is the one year lagged yield risk of $i^{\text {th }}$ crop measured by the standard deviation of two preceding years; $Y R_{2 t-1}$ is the one year lagged yield risk of competing crop measured by the standard deviation of two preceding years; $\beta_{0}$ is the intercept; $\beta_{1-n}$ are the parameter estimates; $\Delta$ is the first difference operator ; and, $\varepsilon$ is the stochastic term.

Following Sadiq, et al (2017) the number of years required for 95 percent of the effect of the price to materialize is:

$(1-r)^{n}=0.05$

Where; $r=$ coefficient of adjustment (1-coefficient of lagged area); and, $n=$ number of year.

\section{Results and Discussions}

\subsection{Trend and Growth Patterns of Root and Tuber Crops in Nigeria}

The results showed both the average annual areas and yields for yam and cassava crops to be on the increase across all the reform periods except that the yield of the cassava plummeted slightly after the SAP era. In the case of potatoes, the average annual area witnessed a steep decline during the SAP era and thereafter marginal rise during the post-SAP era. However, the average annual yield of potatoes maintained a steep plummeted trend throughout the reform periods. This trend behavior showed the crop (potatoes) to be a non-cash crop, has low industrial purpose and little preference as a staple food by the population of the country.

Decomposition analysis showed positive annual growth in the production of all the crops across all the reform periods except for yam during the pre-SAP period whose annual production growth was stagnant. It was observed that the positive annual growth in the output of these crops was due 
to increase in the area and not productivity as the annual growth rate of the latter in most of the reform era was either stagnant or decelerating. In the case of acceleration in productivity, the annual growth rate was very marginal or far below the growth recorded for area.

Comparative analysis across the reform periods showed that annual growth in production of all these crops to be higher during the SAP period with the area increase been the major determinant of the increase in the production of these crops. Furthermore, the results showed that the overall growth in the production of all the crops were positive with the increase been attributed to area and not yield. This implied that technological advancement in respect of yield improvement had little impact on the production of these crops as output increase was determined by area increase and not productivity increase in the country. Therefore, there is need for paradigm shift to sustainable productivity as the pressure on land is surging thereby causing restiveness between herdsmen and arable crop farmers, which at present is causing colossal loss in lives and properties (Table 1 and Figure 1).

Table 1: Annual average and growth patterns of area, yield and production of the selected crops

\begin{tabular}{|c|c|c|c|c|c|}
\hline Crops & Variables & Pre-SAP & SAP & Post-SAP & Overall \\
\hline \multirow[t]{3}{*}{ Yam } & Area & $\begin{array}{l}769416.70 \\
(0.001)^{N S}\end{array}$ & $\begin{array}{c}1644259 \\
(0.007)^{* * *}\end{array}$ & $\begin{array}{c}3403734 \\
(0.003)^{* * *}\end{array}$ & $\begin{array}{c}1744183 \\
(0.003)^{* * *}\end{array}$ \\
\hline & Yield & $\begin{array}{c}8.68 \\
(-0.001)^{N S}\end{array}$ & $9.66(0.003)^{* * *}$ & $9.99(-0.002)^{* *}$ & $9.32(0.00)^{*}$ \\
\hline & Production & $\begin{array}{c}6678536.96 \\
(0.001)^{N S}\end{array}$ & $\begin{array}{c}15883541.90 \\
(0.005)^{* * *}\end{array}$ & $\begin{array}{c}34003302.70 \\
(0.001)^{* * *}\end{array}$ & $\begin{array}{c}16255785.60 \\
(0.002)^{* * *}\end{array}$ \\
\hline \multirow[t]{3}{*}{ Cassava } & Area & $\begin{array}{c}999875 \\
(0.001)^{* * *}\end{array}$ & $\begin{array}{c}2279454 \\
(0.006)^{* * *}\end{array}$ & $\begin{array}{c}4221913 \\
(0.003)^{* * *}\end{array}$ & $\begin{array}{c}2250324 \\
(0.003)^{* * *}\end{array}$ \\
\hline & Yield & $9.77(0.001)^{N S}$ & $10.84(0.000)^{N S}$ & $\begin{array}{c}10.30 \\
(-0.001)^{N S}\end{array}$ & $10.21(0.001)^{N S}$ \\
\hline & Production & $\begin{array}{c}9768778.75 \\
(0.001)^{* * *}\end{array}$ & $\begin{array}{c}24709281.40 \\
(0.003)^{* * *}\end{array}$ & $\begin{array}{c}43485703.90 \\
(0.001)^{* * *}\end{array}$ & $\begin{array}{l}22975808 \\
(0.002)^{* * *}\end{array}$ \\
\hline \multirow[t]{3}{*}{ Potatoes } & Area & $\begin{array}{c}3517.63 \\
(0.008)^{* * *}\end{array}$ & $\begin{array}{l}24806.67 \\
(0.015)^{* * *}\end{array}$ & $\begin{array}{l}268617.50 \\
(0.003)^{* * *}\end{array}$ & $\begin{array}{l}83070.11 \\
(0.012)^{* * *}\end{array}$ \\
\hline & Yield & $\begin{array}{c}8.97 \\
(-0.002)^{* * *}\end{array}$ & $5.97(-0.003)^{* *}$ & $3.23(0.002)^{* *}$ & $6.54(-0.002)^{* * *}$ \\
\hline & Production & $\begin{array}{c}31553.14 \\
(0.002)^{* * *}\end{array}$ & $\begin{array}{l}148095.82 \\
(0.006)^{* * *}\end{array}$ & $\begin{array}{l}867634.53 \\
(0.002)^{* *}\end{array}$ & $\begin{array}{l}543278.52 \\
(0.004)^{* * *}\end{array}$ \\
\hline
\end{tabular}

Note: $* * * * * * \mathrm{NS}$ means significant at $1 \%, 5 \%, 10 \%$ probabilities and Non-significant respectively. Value in parenthesis is estimated annual growth rate 
APT

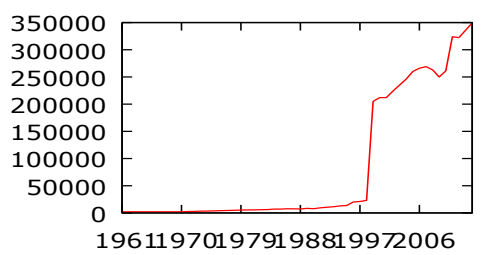

ACS

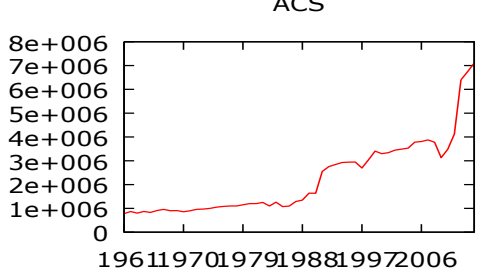

AYM

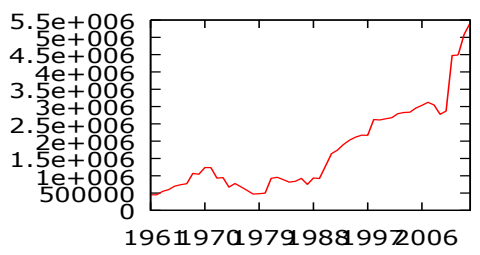

YPT

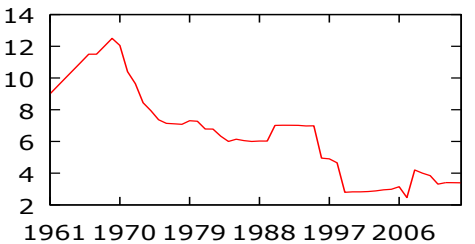

YCS

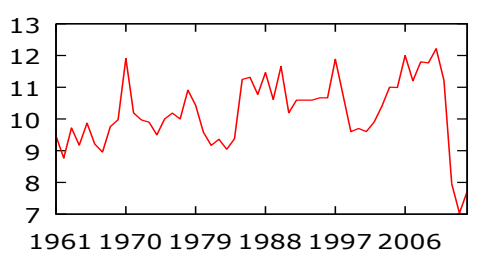

YYM

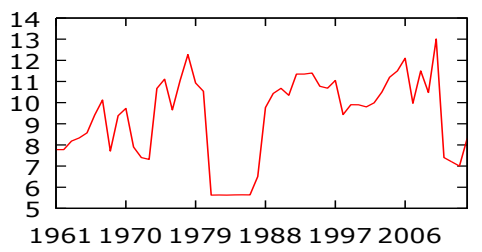

PPT

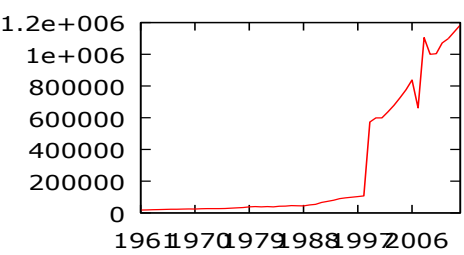

PCS

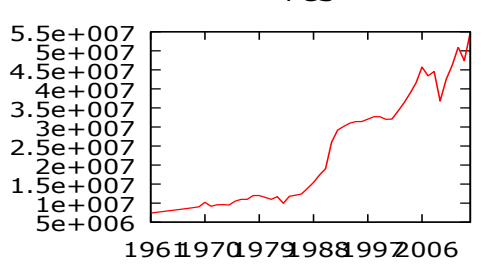

PYM

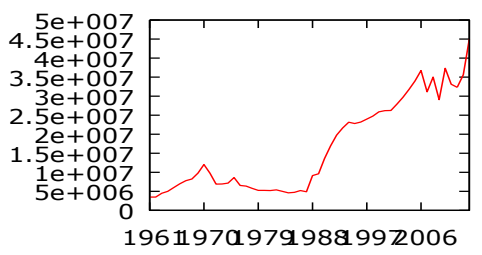

Figure 1: Overall trend of area, yield and production of the selected crops

\subsection{Sources of increase in Outputs of Root and Tuber Crops}

It is imperative to know about the major sources of growth in the output of the root and tuber crops produced in the country (Table 2). A cursory review of the results showed the area effect to be the major source of increase in production of all the selected crops across all the reform periods, inclusive the overall period as evidenced by its estimated percentage contributions which were the highest in the decomposition details and positively signed. The yield effect on the production was found negative for all the crops across the reform periods except during the SAP, pre-SAP and post-SAP for yam, cassava and potatoes respectively. The interaction effect showed negative influence on the production of all crops across the reform periods, inclusive the overall period. It is worth to note that the yield effect for the overall period was found to exert positive effect on output of potatoes and negative for all the remaining crops under study.

Table 2: Sources of increase in output of the selected crops

\begin{tabular}{|c|c|c|c|c|c|}
\hline Crops & Variables & Pre-SAP & SAP & Post-SAP & Overall \\
\hline Yam & Area effect & -32.56 & 11.47 & -14.49 & -1.61 \\
\cline { 2 - 6 } & Yield effect & 419.16 & 89.85 & 159.02 & 131.01 \\
\cline { 2 - 6 } & Interaction effect & -286.6 & -1.32 & -44.53 & -29.40 \\
\hline Cassava & Area effect & 49.08 & -14.31 & -41.02 & -20.87 \\
\cline { 2 - 6 } & Yield effect & 67.19 & 127.83 & 175.90 & 144.94 \\
\cline { 2 - 6 } & Interaction effect & -16.27 & -13.52 & -34.88 & -24.07 \\
\hline Potatoes & Area effect & -50.43 & -11.39 & 27.29 & 7.20 \\
\cline { 2 - 6 } & Yield effect & 159.61 & 174.71 & 80.03 & 126.84 \\
\cline { 2 - 6 } & Interaction effect & -9.18 & -63.32 & -7.32 & -34.04 \\
\hline \multicolumn{5}{|l|}{ Source: Authors' computation, 2018 } \\
\hline
\end{tabular}




\subsection{Instability in the Outputs of Root and Tuber Crops}

The result in Table 3 showed low insatiability in the output of all the crops across the reform periods and the overall period except in the case of yam and potatoes crops which showed moderate instability due to instability in their respective areas during the pre-SAP and SAP periods. So, it is inferred that the production of these crops were almost stable in the country.

Table 3: Level of instability in output of the selected crops

\begin{tabular}{|c|c|c|c|c|c|}
\hline Crops & Variables & Pre-SAP & SAP & Post-SAP & Overall \\
\hline Yam & Area & 15.16 & 1.80 & 4.17 & 6.86 \\
\cline { 2 - 6 } & Yield & 10.65 & 5.87 & 6.83 & 10.02 \\
\cline { 2 - 6 } & Production & 15.96 & 3.60 & 3.07 & 8.34 \\
\hline Cassava & Area & 0.73 & 2.53 & 0.99 & 5.85 \\
\cline { 2 - 6 } & Yield & 3.44 & 2.27 & 4.91 & 3.94 \\
\cline { 2 - 6 } & Production & 1.07 & 2.20 & 1.62 & 7.60 \\
\hline Potatoes & Area & 1.88 & 34.36 & 0.99 & 5.85 \\
\cline { 2 - 6 } & Yield & 3.71 & 7.09 & 4.91 & 3.94 \\
\cline { 2 - 6 } & Production & 0.39 & 18.27 & 1.62 & 7.60 \\
\hline \multicolumn{7}{|l|}{ Source: Authors' computation, 2018 } \\
\hline
\end{tabular}

\subsection{Unit Root Test}

The unit root test results showed that all the variable series were non-stationary at level, but after the first difference they became stationary, that is, the residuals became Gaussian white noise as indicated by their respective estimated ADF tau-statistics which were great and less than their tcritical values at 5 percent probability level respectively. To avert an obscured inference on the validity of the integration order [I(1)] of the variable series obtained from the application of ADF unit root test due to its weakness: residuals are independent and their variance is constant which is not true of time series data, and, the problem of power of sample size; the ADF-GLS test as advocated by Maddalla and Kim (1998); and, Maddalla and Lahiri (2013) was applied to test the robustness and validity of the order of integration. The ADF-GLS unit root test at level and at first difference accepted the null hypothesis of non-stationary against the alternative hypothesis for all the variable series and rejected the null hypothesis in favour of the alternative hypothesis of stationary for all the variable series at 5 percent probability level respectively (Table 4 ). Therefore, it can be inferred that all the variable series are integrated of order one.

Table 4: Stationarity test

\begin{tabular}{|c|c|c|c|c|}
\hline Variables & Stage & \multicolumn{3}{|c|}{ ADF } \\
\cline { 2 - 5 } & & Yam $($ YM) & Cassava $(\mathbf{C})$ & Potatoes $($ PT) \\
\hline \multirow{2}{*}{ Area (A) } & Level & $-0.189(0.93)^{\mathrm{NS}}$ & $-3.38(0.147)^{\mathrm{NS}}$ & $-1.477(0.527)^{\mathrm{NS}}$ \\
\cline { 2 - 5 } & $1^{\text {st }} \Delta$ & $-4.86(8.6 \mathrm{E}-4)^{\mathrm{S}}$ & $-4.251(0.015)^{\mathrm{S}}$ & $-4.683(1.3 \mathrm{E}-3)^{\mathrm{S}}$ \\
\hline \multirow{2}{*}{ Yield (Y) } & Level & $-2.265(0.19)^{\mathrm{NS}}$ & $-2.580(0.097)^{\mathrm{NS}}$ & $-1.807(0.368)^{\mathrm{NS}}$ \\
\cline { 2 - 5 } & $1^{\text {st }} \Delta$ & $-6.68(1.5 \mathrm{E}-5)^{\mathrm{S}}$ & $-3.447(0.02)^{\mathrm{S}}$ & $-5.631(1.5 \mathrm{E}-4)^{\mathrm{S}}$ \\
\hline \multirow{2}{*}{ Price (P) } & Level & $-2.466(0.136)^{\mathrm{NS}}$ & $-2.357(0.164)^{\mathrm{NS}}$ & $-1.578(0.49)^{\mathrm{NS}}$ \\
\cline { 2 - 5 } & $1^{\text {st }} \Delta$ & $-4.991(6.4 \mathrm{E}-4)^{\mathrm{S}}$ & $-5.246(3.6 \mathrm{E}-4)^{\mathrm{S}}$ & $-5.185(8.4 \mathrm{E}-6)^{\mathrm{S}}$ \\
\hline Yield risk (YR) & Level & $-0.521(0.491)^{\mathrm{NS}}$ & $-0.960(0.291)^{\mathrm{NS}}$ & $-2.927(0.058)^{\mathrm{NS}}$ \\
\hline
\end{tabular}


DOI: $10.5281 /$ zenodo.2585567

\begin{tabular}{|c|c|c|c|c|}
\hline & $1^{\text {st }} \Delta$ & $-7.80(1.58 \mathrm{E}-13)^{\mathrm{S}}$ & $-6.210(1.7 \mathrm{E}-6)^{\mathrm{S}}$ & $-6.962(7.85 \mathrm{E}-6)^{\mathrm{S}}$ \\
\hline \multirow{2}{*}{ Price risk (PR) } & Level & $-1.042(0.269)^{\mathrm{NS}}$ & $-1.065(0.250)^{\mathrm{NS}}$ & $-1.179(0.219)^{\mathrm{NS}}$ \\
\cline { 2 - 6 } & $1^{\text {st }} \Delta$ & $-5.560(4.64 \mathrm{E}-8)^{\mathrm{S}}$ & $-5.139(2.25 \mathrm{E}-5)^{\mathrm{S}}$ & $-5.363(1.26 \mathrm{E}-7)^{\mathrm{S}}$ \\
\hline
\end{tabular}

Note: $\Delta$, NS and $\mathrm{S}$ indicates first difference, non-stationary and stationary at the level or at first difference at 5 percent significance

\subsection{Co-integration Test}

Given that all the variable series are integrated of order one, co-integration test was conducted to see whether the variables shared one stochastic trend or not. The results of the ADF unit root test applied to the generated residual from the first step of each of the selected crops long-run acreage and yield responses models of the Engel-Granger two step procedure indicated that both the residual variables were stationary as evident by their respective tau-statistics which were lower than the Engel-Granger critical value at 5 percent probability level (Table 5). Thus, it implies that these variables in each case, that is, acreage and yield responses direction have long-run association or move together in the long-run (that is, they shared one stochastic trend). Therefore, these outcomes indicated that the estimated parameters of the long-run model of the acreage and yield responses of the neo classical adaptive model are reliable for long-run prediction. However, the case of spurious regression was not observed in all the first step regression for the acreage and supply response adjustment models of the Engel-Granger two step procedure as all their respective coefficient of determination were lower than their Durbin-Watson statistic ( $\mathrm{R}^{\wedge} 2<\mathrm{D}-\mathrm{W}$ statistic).

Table 5: Co-integration test

\begin{tabular}{|c|c|c|c|c|c|}
\hline \multirow{2}{*}{ Residual (U) } & \multicolumn{2}{|c|}{$\tau$-statistic } & \multicolumn{2}{c|}{ Engel-Granger critical value } & \multirow{2}{*}{ Decision } \\
\cline { 2 - 5 } & Area & Yield & 5 percent & 10 percent & \\
\hline Yam & $-6.771^{*}$ & $-4.989^{*}$ & -3.34 & -3.04 & Stationary at level I (0) \\
\hline Cassava & $-5.903^{*}$ & $-4.397^{*}$ & -3.34 & -3.04 & Stationary at level I (0) \\
\hline Potatoes & $-7.034^{*}$ & $-5.715^{*}$ & -3.34 & -3.04 & Stationary at level I (0) \\
\hline Note: * indicate that unit root at the level was rejected at 5 percent significant level \\
\hline
\end{tabular}

\subsection{Farmers' Acreage Responses for Root and Tuber Crops}

\subsubsection{Long-Run Acreage Response}

The results showed that the farmers' decision on the current acreage allocation to yam, cassava and potatoes in the long-run were significantly influenced by the lagged prices of yam and cassava, lagged price and yield risks of potatoes, lagged acreage and yield of potatoes, lagged acreage allocated to cassava and lagged yield of yam; the lagged price of yam, lagged acreage allocated to yam and potatoes, and lagged yield of potatoes; and, the lagged cassava yield risk respectively, as evident from their respective coefficients which were different from zero at 10 percent degree of freedom. The elasticity implication of a percent increase in the lagged cassava price, lagged cassava acreage and lagged yam yield would influence the decision of the farmers to increase their current acreage allocation to yam by 0.56 percent, 0.77 percent and 1.05 percent respectively; while a percent increase in the lagged yam price, lagged potatoes yield risk, lagged potatoes price risk, lagged potatoes acreage and yield would make the farmers to decrease the current yam acreage allocation by 0.59 percent, 0.01 percent, 0.05 percent, 0.15 percent and 0.40 percent 
respectively. Furthermore, the elasticity implication of a percent increase in the lagged yam acreage would increase the current cassava acreage by 1.12 percent; while a percent increase in the lagged yam price, lagged potatoes acreage and yield will decrease the current cassava acreage allocation by 0.25 percent, 0.21 percent and 0.34 percent respectively. Also, the current acreage of potatoes will increase by 0.08 percent for a percent increase in the lagged cassava yield risk. Observation showed that the yam and cassava acreage responses exhibited elastic relationships with lagged yam yield and acreage respectively; while the lagged cassava price and acreage; and, lagged cassava yield risk had inelastic relationship with the yam and potatoes acreage responses respectively. In addition, it is pertinent to note that the significant coefficients with negative sign: less than unity and greater than unity implies inverse inelastic and elastic relationships with the acreage response respectively; while the positively signed significant coefficients: less than unity and greater than unity implies direct inelastic and elastic relationships with the acreage response respectively.

Observed from the results is that 97 percent, 99 percent and 93.7 percent of the variation in the current acreage response for yam, cassava and potatoes were influenced by the price and non-price factors captured by the long-run adaptive dynamic models.

Based on the yam acreage response findings, it can be inferred that the farmers were vary of the convergent cobweb effect which will likely result in glut in the subsequent year in lieu of the previous remunerative price of yam. In addition, potatoes' crop is a competing crop with yam crop as evident by its non-price factor negative effect while the remunerative price for cassava will encourage the farmers to increase acreage allocation to yam in order to take advantage of convergent cobweb effect that will occur with cassava crop as both crops are good substitute in terms of food consumption and industrial purpose. Therefore, yam featured to be a competing crop with cassava crop. The lagged yam productivity positively influenced the decision of the farmers on the current acreage allocation to yam. For the potatoes crop, the fluctuation in the cassava yield risk will make the farmers to shift their acreage resource to the production of potatoes in the subsequent year in order to compensate for the loss recorded due to the poor yield of cassava in the lagged period (Table 6).

Table 6: Long-run acreage and yield responses of the selected crop farmers

\begin{tabular}{|c|c|c|c|c|c|c|}
\hline $\begin{array}{l}\text { Varia } \\
\text { bles }\end{array}$ & $\ln A Y M_{t}$ & $\ln A C_{t}$ & $\ln A P T_{t}$ & $\ln Y Y M_{t}$ & $\ln Y C_{t}$ & $\ln Y P T_{t}$ \\
\hline $\begin{array}{c}\text { Interc } \\
\text { ept }\end{array}$ & $\begin{array}{c}- \\
15.74(5.891)[2 \\
.67]^{* *}\end{array}$ & $\begin{array}{c}10.50(5.16)[2 \\
.04]^{*}\end{array}$ & $\begin{array}{r}1.929(14 \\
.133\end{array}$ & $\begin{array}{c}19.84(5.906)[ \\
3.36]^{* *}\end{array}$ & $\begin{array}{c}8.617(2.151)[4 . \\
01]^{* * *}\end{array}$ & $\begin{array}{c}21.82(6.93)[3 . \\
15]^{* *}\end{array}$ \\
\hline$\underset{M_{t-1}}{\ln A Y}$ & $\begin{array}{c}0.823(0.452)[1 \\
.82]\end{array}$ & $\begin{array}{c}1.116(0.503)[ \\
2.22]^{*}\end{array}$ & $\begin{array}{c}5.035(3.924)[1 \\
.28]^{\mathrm{NS}}\end{array}$ & $\begin{array}{c}0.094(0.489)[ \\
0.19]^{\mathrm{NS}}\end{array}$ & $\begin{array}{c}- \\
0.284(0.296)[0 . \\
96]^{\mathrm{NS}}\end{array}$ & $\begin{array}{c}2.700(0.852)[ \\
3.17]^{* *}\end{array}$ \\
\hline$\underset{1}{\ln A C_{t-}}$ & $\begin{array}{c}0.769(0.371)[2 \\
.07]^{*}\end{array}$ & $\begin{array}{c}0.538(0.377)[ \\
1.43]^{\mathrm{NS}}\end{array}$ & $\begin{array}{c}3.597(3.316)[1 \\
.09]^{\mathrm{NS}}\end{array}$ & $\begin{array}{c}0.422(0.380)[ \\
1.11]^{\mathrm{NS}}\end{array}$ & $\begin{array}{c}0.074(0.239)[0 . \\
31]^{\mathrm{NS}}\end{array}$ & $\begin{array}{c}1.777(0.698)[ \\
2.55]^{* *}\end{array}$ \\
\hline$\underset{t-1}{\ln A P T}$ & $\begin{array}{c}- \\
0.149(0.051)[2 \\
.91]^{* *}\end{array}$ & $\begin{array}{c}0.210(0.066)[ \\
3.17]^{* *}\end{array}$ & $\begin{array}{c}0.323(0.317)[1 \\
.02]^{\mathrm{NS}}\end{array}$ & $\begin{array}{c}0.047(0.061)[ \\
0.77]^{\mathrm{NS}}\end{array}$ & $\begin{array}{c}0.049(0.024)[2 . \\
02]^{*}\end{array}$ & $\begin{array}{c}0.010(0.072)[ \\
1.38]^{\mathrm{NS}}\end{array}$ \\
\hline$\underset{\mathbf{P}_{\mathrm{t}-1}}{\ln Y M}$ & $\begin{array}{c}- \\
0.589(0.120)[4 \\
.92]^{* * *}\end{array}$ & $\begin{array}{c}- \\
0.248(0.102)[ \\
2.42]^{*}\end{array}$ & $\begin{array}{c}0.230(0.633)[0 \\
.363]^{\mathrm{NS}}\end{array}$ & $\begin{array}{c}0.333(0.115)[ \\
2.91]^{* *}\end{array}$ & $\begin{array}{c}0.006(0.040)[0 . \\
14]^{\mathrm{NS}}\end{array}$ & $\begin{array}{c}- \\
0.054(0.134)[ \\
0.39]^{\mathrm{NS}}\end{array}$ \\
\hline
\end{tabular}


DOI: 10.5281/zenodo.2585567

\begin{tabular}{|c|c|c|c|c|c|c|}
\hline$\underset{1}{\operatorname{lnC} \mathbf{P}_{t-}}$ & $\begin{array}{c}0.561(0.1250[ \\
4.50]^{* * *}\end{array}$ & $\begin{array}{c}0.071(0.133)[ \\
0.53]^{\mathrm{NS}}\end{array}$ & $\begin{array}{c}0.229(0.942)[0 \\
.244]^{\mathrm{NS}}\end{array}$ & $\begin{array}{c}0.368(0.112)[ \\
3.29]^{* *}\end{array}$ & $\begin{array}{c}0.063(0.059)[1 . \\
06]^{\mathrm{NS}}\end{array}$ & $\begin{array}{c}0.048(0.196)[ \\
0.24]^{\mathrm{NS}}\end{array}$ \\
\hline$\underset{t-1}{\ln P T P}$ & $\begin{array}{c}0.055(0.063)[0 \\
.88]^{\mathrm{NS}}\end{array}$ & $\begin{array}{c}0.007(0.064)[ \\
0.11]^{\mathrm{NS}}\end{array}$ & $\begin{array}{c}0.0009(0.259)[ \\
0.004]^{\mathrm{NS}}\end{array}$ & $\begin{array}{c}- \\
0.170(0.087)[ \\
1.95]^{*}\end{array}$ & $\begin{array}{c}- \\
0.032(0.024)[1 . \\
36]^{\mathrm{NS}}\end{array}$ & $\begin{array}{c}0.278(0.064)[ \\
4.36]^{* * *}\end{array}$ \\
\hline $\begin{array}{l}\operatorname{lnYM} \\
\text { PR }_{t-1}\end{array}$ & $\begin{array}{c}0.017(0.021)[0 \\
.80]^{\mathrm{NS}}\end{array}$ & $\begin{array}{c}0.021(0.018)[ \\
1.19]^{\mathrm{NS}}\end{array}$ & $\begin{array}{c}0.077(0.056)[1 \\
.38]^{\mathrm{NS}}\end{array}$ & $\begin{array}{c}- \\
0.050(0.021)[ \\
2.40]^{*} \\
\end{array}$ & $\begin{array}{c}- \\
0.034(0.013)[2 . \\
58]^{* *} \\
\end{array}$ & $\begin{array}{c}- \\
0.084(0.023)[ \\
3.63]^{* *}\end{array}$ \\
\hline$\underset{t-1}{\ln C P R}$ & $\begin{array}{c}- \\
0.005(0.008)[0 \\
.59]^{\mathrm{NS}} \\
\end{array}$ & $\begin{array}{c}- \\
0.009(0.017)[ \\
0.52]^{\mathrm{NS}} \\
\end{array}$ & $\begin{array}{c}0.076(0.064)[1 \\
.19]^{\mathrm{NS}}\end{array}$ & $\begin{array}{c}0.017(0.020)[ \\
0.86]^{\mathrm{NS}}\end{array}$ & $\begin{array}{c}0.012(0.010)[1 . \\
14]^{\mathrm{NS}}\end{array}$ & $\begin{array}{c}0.033(0.023)[ \\
1.41]^{\mathrm{NS}}\end{array}$ \\
\hline $\begin{array}{c}\ln P T P \\
\mathbf{R}_{t-1}\end{array}$ & $\begin{array}{c}- \\
0.050(0.017)[2 \\
.86]^{* *}\end{array}$ & $\begin{array}{c}- \\
0.025(0.021)[ \\
1.17]^{\mathrm{NS}} \\
\end{array}$ & $\begin{array}{c}- \\
0.015(0.101)[0 \\
.15]^{\mathrm{NS}} \\
\end{array}$ & $\begin{array}{c}0.096(0.021)[ \\
4.54]^{* * *}\end{array}$ & $\begin{array}{c}0.039(0.012)[3 \\
05]^{* *}\end{array}$ & $\begin{array}{c}0.033(0.038)[ \\
0.85]^{\mathrm{NS}}\end{array}$ \\
\hline $\begin{array}{c}\ln Y Y \\
\mathbf{M}_{t-1}\end{array}$ & $\begin{array}{c}1.006(0.357)[2 \\
.82]^{* *}\end{array}$ & $\begin{array}{c}0.303(0.336)[ \\
0.90]^{\mathrm{NS}}\end{array}$ & $\begin{array}{c}2.294(1.568)[1 \\
.46]^{\mathrm{NS}}\end{array}$ & $\begin{array}{c}- \\
0.579(0.463)[ \\
1.25]^{\mathrm{NS}} \\
\end{array}$ & $\begin{array}{c}0.127(0.194)[0 . \\
66]^{\mathrm{NS}}\end{array}$ & $\begin{array}{c}- \\
2.228(0.482)[ \\
4.63] * * *\end{array}$ \\
\hline$\underset{1}{\ln \mathrm{YC}_{\mathrm{t}}-}$ & $\begin{array}{c}0.135(0.278)[0 \\
.49]^{\mathrm{NS}}\end{array}$ & $\begin{array}{c}0.403(0.328)[ \\
1.23]^{\mathrm{NS}}\end{array}$ & $\begin{array}{c}2.829(2.564)[1 \\
.10]^{\mathrm{NS}}\end{array}$ & $\begin{array}{c}0.298(0.312)[ \\
0.96]^{\mathrm{NS}}\end{array}$ & $\begin{array}{c}0.400(0.185)[2 . \\
16]^{*}\end{array}$ & $\begin{array}{c}1.771(0.715)[ \\
2.48]^{* *}\end{array}$ \\
\hline$\underset{t-1}{\ln Y P T}$ & $\begin{array}{c}- \\
0.400(0.162)[2 \\
.47]^{* *}\end{array}$ & $\begin{array}{c}0.337(0.162)[ \\
2.08]^{*}\end{array}$ & $\begin{array}{c}0.892(0.482)[1 \\
.85]^{\mathrm{NS}}\end{array}$ & $\begin{array}{c}0.034(0.203)[ \\
0.17]^{\mathrm{NS}}\end{array}$ & $\begin{array}{c}0.072(0.066)[1 . \\
10]^{\mathrm{NS}}\end{array}$ & $\begin{array}{c}0.444(0.150)[ \\
2.96]^{* *}\end{array}$ \\
\hline $\begin{array}{r}\ln Y M \\
\mathbf{Y R}_{\mathrm{t}-1}\end{array}$ & $\begin{array}{c}0.016(0.012)[1 \\
.33]^{\mathrm{NS}}\end{array}$ & $\begin{array}{c}0.002(0.012)[ \\
0.14]^{\mathrm{NS}}\end{array}$ & $\begin{array}{c}0.001(0.032)[0 \\
.039]^{\mathrm{NS}}\end{array}$ & $\begin{array}{c}0.002(0.010)[ \\
0.23]^{\mathrm{NS}}\end{array}$ & $\begin{array}{c}0.021(0.004)[4 . \\
45]^{* * *}\end{array}$ & $\begin{array}{c}0.038(0.012)[ \\
3.31]^{* *}\end{array}$ \\
\hline $\begin{array}{c}\ln C Y \\
\mathbf{R}_{\mathrm{t}-1}\end{array}$ & $\begin{array}{c}0.004(0.007)[0 \\
.51]^{\mathrm{NS}}\end{array}$ & $\begin{array}{c}0.005(0.009)[ \\
0.55]^{\mathrm{NS}}\end{array}$ & $\begin{array}{c}0.076(0.037)[2 \\
.050]^{*}\end{array}$ & $\begin{array}{c}0.027(0.007)[ \\
3.99]^{* * *}\end{array}$ & $\begin{array}{c}0.028(0.003)[1 \\
0.96]^{* * *}\end{array}$ & $\begin{array}{c}0.060(0.012)[ \\
4.85]^{* * *}\end{array}$ \\
\hline $\begin{array}{c}\ln P T Y \\
\mathbf{R}_{t-1}\end{array}$ & $\begin{array}{c}- \\
0.013(0.007)[2 \\
.08]^{*} \\
\end{array}$ & $\begin{array}{c}- \\
0.016(0.010)[ \\
1.56]^{\mathrm{NS}} \\
\end{array}$ & $\begin{array}{c}0.004(0.041)[0 \\
.091]^{\mathrm{NS}}\end{array}$ & $\begin{array}{c}- \\
0.011(0.008)[ \\
1.45]^{\mathrm{NS}}\end{array}$ & $\begin{array}{c}0.005(0.003)[1 . \\
68]^{\mathrm{NS}}\end{array}$ & $\begin{array}{c}0.002(0.014)[ \\
0.13]^{\mathrm{NS}}\end{array}$ \\
\hline $\mathbf{R}^{2}$ & 0.97 & 0.99 & 0.937 & 0.863 & 0.974 & 0.929 \\
\hline $\begin{array}{c}\text { D-W } \\
\text { stat }\end{array}$ & 2.48 & 2.45 & 2.85 & 2.10 & 1.70 & 3.91 \\
\hline F-stat & $\begin{array}{c}395.89\{1.03 \mathrm{E}- \\
7\}^{* * *}\end{array}$ & $\begin{array}{c}39.97\{0.000\} \\
* * *\end{array}$ & $\begin{array}{c}1578.35\{1.6 \mathrm{E}- \\
9\} * * *\end{array}$ & $\begin{array}{l}69.94\{1.8 \mathrm{E}- \\
5\}^{* * *}\end{array}$ & $\begin{array}{c}662.1\{2.2 \mathrm{E}- \\
8\}^{* * *}\end{array}$ & $\begin{array}{c}599.9\{2.9 \mathrm{E}- \\
8\}^{* * *}\end{array}$ \\
\hline
\end{tabular}

\subsubsection{Short-Run Acreage Response}

The attractor coefficients of the short-run acreage response model of all the selected crops had the appropriate sign and were significant at 10 percent risk level, an indication that the farmers' current acreage allocation for yam, cassava and potatoes have long-run equilibrium. The implication is that the short-run acreage response for yam, cassava and potatoes corrects their disequilibria at the speed of 182.6 percent, 189.6 percent and 271.3 percent respectively. In addition, the time period required for the current acreage allocation to yam, cassava and potatoes to establish equilibrium would be approximately 22, 23 and 33 months respectively. Therefore, it can be inferred that the efficiency of farmers' acreage response to any innovation that might arise from any of the shortrun parameters is very low which might be due to their low technical know-how, poor capital base and low technological advancements. 
The results showed that with the exception of the potatoes price and non-price factors, all the remaining factors had short-run causal effect on the farmers' decision on the current yam acreage as evidenced by the significance of their respective coefficients at equal or less than 10 percent probability level. Furthermore, the price and non-price factors that have causal effects on farmers' decision on the current acreage allocation for cassava and potatoes crops were lagged yam price, lagged potatoes yield risk, lagged potatoes acreage and yield, lagged yam and cassava acreages, and the lagged price risk of yam; and, lagged yam and cassava prices, and lagged area and yield of yam and cassava respectively. Therefore, a percent increase in the lagged yam price, lagged cassava and potatoes yield risks, lagged potatoes yield, and, lagged cassava and potatoes price risks will make the farmers to decrease their current yam acreage by 1.18 percent, 0.02 percent, 0.03 percent, 0.31 percent, 0.02 percent and 0.07 percent respectively; while a percent increase in the lagged cassava price, lagged yam area and yield, and, lagged cassava area and yield will increase the current yam acreage by 1.39 percent, 0.76 percent, 1.21 percent, 1.88 percent and 0.65 percent respectively. Furthermore, a percent increase in the lagged yam price, lagged potatoes yield risk, lagged potatoes area and yield will decrease current cassava acreage by 0.29 percent, 0.03 percent, 0.21 percent and 0.41 percent respectively; while a percent increase in the lagged yam and cassava areas, and lagged yam price risk will increase current cassava acreage by 1.17 percent, 0.89 percent and 0.02 percent respectively. A percent increase in the lagged cassava price, lagged cassava area and yield will decrease the current potatoes acreage by 1.44 percent, 4.52 percent and 4.30 percent respectively; while a percent increase in the lagged yam price, lagged yam area and yield will increase the current potatoes acreage by 0.58 percent, 7.01 percent and 4.06 percent respectively (Table 7).

Table 7: Short-run acreage and yield responses of the selected crop farmers

\begin{tabular}{|c|c|c|c|c|c|c|}
\hline $\begin{array}{c}\text { Varia } \\
\text { bles }\end{array}$ & $\Delta A Y M_{t}$ & $\Delta A C_{t}$ & $\Delta A P T_{t}$ & $\Delta Y Y M_{t}$ & $\Delta Y C_{t}$ & $\Delta Y P T_{t}$ \\
\hline $\begin{array}{c}\text { Interc } \\
\text { ept }\end{array}$ & $\begin{array}{c}- \\
0.063(0.019)[3 \\
.33]^{* *}\end{array}$ & $\begin{array}{c}- \\
0.010(0.018)[0 \\
.57]^{\mathrm{NS}}\end{array}$ & $\begin{array}{c}0.032(0.049)[0 \\
.66]^{\mathrm{NS}}\end{array}$ & $\begin{array}{c}0.029(0.010)[2 \\
.88]^{* *}\end{array}$ & $\begin{array}{c}0.011(0.005)[2 \\
.53]^{*}\end{array}$ & $\begin{array}{c}-\overline{-} \\
0.006(0.016)[0 \\
.36]^{\mathrm{NS}}\end{array}$ \\
\hline$\underset{M_{t-1}}{\ln A Y}$ & $\begin{array}{c}0.755(0.115)[6 \\
.59]^{* * *}\end{array}$ & $\begin{array}{c}1.174(0.276)[4 \\
.25]^{* *}\end{array}$ & $\begin{array}{r}7.011(0 . \\
.36]^{*}\end{array}$ & $\begin{array}{r}0.578(0 \\
.23\end{array}$ & $\begin{array}{c}0.281(0.076)[3 \\
.68]^{* *} \\
\end{array}$ & $\begin{array}{c}2.847(0.287)[9 \\
.92]^{* * *}\end{array}$ \\
\hline $\begin{array}{c}\ln A_{C_{t}-} \\
1\end{array}$ & $\begin{array}{c}1.878(0.296)[6 \\
.35]^{* * *}\end{array}$ & $\begin{array}{c}0.891(0.389)[2 \\
.29]^{*}\end{array}$ & $\begin{array}{c}- \\
4.515(0.680)[6 \\
.64]^{* * *}\end{array}$ & $\begin{array}{c}- \\
1.129(0.285)[3 \\
.97]^{* *}\end{array}$ & $\begin{array}{c}-\overline{-} \\
0.281(0.084)[3 \\
.36]^{* *}\end{array}$ & $\begin{array}{c}1.539(0.314)[4 \\
.91]^{* * *}\end{array}$ \\
\hline$\underset{t-1}{\ln A P T}$ & $\begin{array}{c}0.059(0.047)[1 \\
.26]^{\mathrm{NS}}\end{array}$ & $\begin{array}{c}- \\
0.208(0.054)[3 \\
.85]^{* * *}\end{array}$ & $\begin{array}{c}0.060(0.198)[0 \\
.30]^{\mathrm{NS}}\end{array}$ & $\begin{array}{c}- \\
0.102(0.022)[4 \\
.60]^{* * *}\end{array}$ & $\begin{array}{c}0.025(0.008)[3 \\
.29]^{* *}\end{array}$ & $\begin{array}{c}0.195(0.061)[3 \\
.20]^{* *}\end{array}$ \\
\hline$\underset{\mathbf{P}_{t-1}}{\ln Y M}$ & $\begin{array}{c}- \\
1.180(0.134)[8 \\
.82]^{* * *}\end{array}$ & $\begin{array}{c}0.294(0.138)[2 \\
.14]^{*}\end{array}$ & $\begin{array}{c}0.583(0.225)[2 \\
.59]^{*}\end{array}$ & $\begin{array}{c}0.629(0.113)[5 \\
.58]^{* * *}\end{array}$ & $\begin{array}{c}0.071(0.031)[2 \\
.33]^{*}\end{array}$ & $\begin{array}{c}- \\
0.144(0.133)[1 \\
.09]^{\mathrm{NS}} \\
\end{array}$ \\
\hline$\underset{1}{\operatorname{lnC} C P_{t}}$ & $\begin{array}{c}1.386(0.169)[8 \\
.19]^{* * *}\end{array}$ & $\begin{array}{c}0.150(0.170)[0 \\
.88]^{\mathrm{NS}}\end{array}$ & $\begin{array}{c}1.438(0.4180[ \\
3.44]^{* *}\end{array}$ & $\begin{array}{c}- \\
0.897(0.137)[6 \\
.54]^{* * *}\end{array}$ & $\begin{array}{c}- \\
0.037(0.041)[0 \\
.90]^{\mathrm{NS}}\end{array}$ & $\begin{array}{c}0.258(0.142)[1 \\
.81]^{\mathrm{NS}}\end{array}$ \\
\hline$\underset{t-1}{\ln P T P}$ & $\begin{array}{c}- \\
0.014(0.019)[0 \\
.71]^{\mathrm{NS}} \\
\end{array}$ & $\begin{array}{c}0.029(0.052)[0 \\
.56]^{\mathrm{NS}} \\
\end{array}$ & $\begin{array}{c}0.233(0.135)[1 \\
.73]^{\mathrm{NS}}\end{array}$ & $\begin{array}{c}0.169(0.023)[7 \\
.28]^{* * *} \\
\end{array}$ & $\begin{array}{c}0.007(0.013)[0 \\
.53]^{\mathrm{NS}} \\
\end{array}$ & $\begin{array}{c}0.216(0.038)[5 \\
.76]^{* * *}\end{array}$ \\
\hline $\begin{array}{l}\operatorname{lnYM} \\
\text { PR }_{t-1}\end{array}$ & $\begin{array}{c}0.015(0.011)[1 \\
.44]^{\mathrm{NS}}\end{array}$ & $\begin{array}{c}0.022(0.010)[2 \\
.15]^{*}\end{array}$ & $\begin{array}{c}0.079(0.054)[1 \\
.47]^{\mathrm{NS}}\end{array}$ & $\begin{array}{c}0.029(0.009)[3 \\
.04]^{* *}\end{array}$ & $\begin{array}{c}0.032(0.005)[6 \\
.04]^{* * *}\end{array}$ & $\begin{array}{c}0.095(0.013)[7 \\
.21]^{* * *}\end{array}$ \\
\hline
\end{tabular}




\begin{tabular}{|c|c|c|c|c|c|c|}
\hline$\underset{t-1}{\operatorname{lnCPR}}$ & $\begin{array}{c}0.021(0.003)[7 \\
.85]^{* * *}\end{array}$ & $\begin{array}{c}0.016(0.009)[1 \\
.67]^{\mathrm{NS}}\end{array}$ & $\begin{array}{c}0.017(0.016)[1 \\
.03]^{\mathrm{NS}}\end{array}$ & $\begin{array}{c}0.032(0.004)[8 \\
.42]^{* * *}\end{array}$ & $\begin{array}{c}0.020(0.004)[5 \\
.51]^{* * *}\end{array}$ & $\begin{array}{c}0.043(0.007)[6 \\
.45]^{* * *}\end{array}$ \\
\hline $\begin{array}{c}\ln P T P \\
\mathbf{R}_{t-1}\end{array}$ & $\begin{array}{c}- \\
0.073(0.006)[1 \\
2.3]^{* * *} \\
\end{array}$ & $\begin{array}{c}0.025(0.013)[1 \\
.96]^{\mathrm{NS}}\end{array}$ & $\begin{array}{c}0.042(0.070)[0 \\
.59]^{\mathrm{NS}}\end{array}$ & $\begin{array}{c}0.104(0.011)[9 \\
.13]^{* * *}\end{array}$ & $\begin{array}{c}0.040(0.006)[6 \\
.31]^{* * *}\end{array}$ & $\begin{array}{c}0.013(0.007)[1 \\
.82]^{\mathrm{NS}}\end{array}$ \\
\hline $\begin{array}{c}\ln Y Y \\
\mathbf{M}_{t-1}\end{array}$ & $\begin{array}{c}1.212(0.071)[1 \\
6.9]^{* * *}\end{array}$ & $\begin{array}{c}0.407(0.209)[1 \\
.94]^{\mathrm{NS}}\end{array}$ & $\begin{array}{c}4.064(0.523)[7 \\
.77]^{* * *}\end{array}$ & $\begin{array}{c}- \\
0.416(0.110)[3 \\
.78]^{* *}\end{array}$ & $\begin{array}{c}0.050(0.055)[0 \\
.91]^{\mathrm{NS}}\end{array}$ & $\begin{array}{c}- \\
2.319(0.158)[1 \\
4.7]^{* * *}\end{array}$ \\
\hline $\begin{array}{c}\ln Y C_{t-} \\
1 \\
\end{array}$ & $\begin{array}{c}0.648(0.221)[2 \\
.94]^{* *}\end{array}$ & $\begin{array}{c}0.670(0.376)[1 \\
.78]^{\mathrm{NS}}\end{array}$ & $\begin{array}{c}- \\
4.296(1.059)[4 \\
.06]^{* *} \\
\end{array}$ & $\begin{array}{c}- \\
0.160(0.246)[0 \\
.65]^{\mathrm{NS}}\end{array}$ & $\begin{array}{c}0.124(0.111)[1 \\
.11]^{\mathrm{NS}}\end{array}$ & $\begin{array}{c}1.432(0.259)[5 \\
.52]^{* * *}\end{array}$ \\
\hline $\begin{array}{c}\ln Y P T \\
t-1\end{array}$ & $\begin{array}{c}- \\
0.310(0.053)[5 \\
.86]^{* * *}\end{array}$ & $\begin{array}{c}- \\
0.407(0.096)[4 \\
.23]^{* *}\end{array}$ & $\begin{array}{c}- \\
0.401(0.356)[1 \\
.13]^{\mathrm{NS}}\end{array}$ & $\begin{array}{c}0.124(0.060)[2 \\
.08]^{\mathrm{NS}}\end{array}$ & $\begin{array}{c}- \\
0.032(0.033)[0 \\
.95]^{\mathrm{NS}}\end{array}$ & $\begin{array}{c}0.620(0.057)[1 \\
0.8]^{* * *}\end{array}$ \\
\hline $\begin{array}{c}\ln Y M \\
\mathbf{Y R}_{\mathrm{t}-1}\end{array}$ & $\begin{array}{c}0.063(0.010)[6 \\
.44]^{* * *}\end{array}$ & $\begin{array}{c}0.010(0.010)[1 \\
.01]^{\mathrm{NS}}\end{array}$ & $\begin{array}{c}- \\
0.006(0.023)[0 \\
.25]^{\mathrm{NS}} \\
\end{array}$ & $\begin{array}{c}- \\
0.025(0.006)[4 \\
.37]^{* *} \\
\end{array}$ & $\begin{array}{c}0.013(0.002)[8 \\
.47]^{* * *}\end{array}$ & $\begin{array}{c}0.044(0.013)[3 \\
.42]^{* *}\end{array}$ \\
\hline $\begin{array}{c}\ln C Y \\
\mathbf{R}_{\mathbf{t}-1}\end{array}$ & $\begin{array}{c}- \\
0.018(0.007)[2 \\
.56]^{*}\end{array}$ & $\begin{array}{c}- \\
0.001(0.008)[0 \\
.10]^{\mathrm{NS}}\end{array}$ & $\begin{array}{c}0.031(0.028)[1 \\
.09]^{\mathrm{NS}}\end{array}$ & $\begin{array}{c}- \\
0.015(0.004)[3 \\
.86]^{* *}\end{array}$ & $\begin{array}{c}- \\
0.021(0.002)[9 \\
.39]^{* * *}\end{array}$ & $\begin{array}{c}- \\
0.046(0.011)[4 \\
.08]^{* * *}\end{array}$ \\
\hline$\underset{\mathbf{R}_{t-1}}{\operatorname{lnPTY}}$ & $\begin{array}{c}- \\
0.034(0.004)[7 \\
.88]^{* * *}\end{array}$ & $\begin{array}{c}0.025(0.008)[3 \\
.13]^{* *}\end{array}$ & $\begin{array}{c}0.047(0.027)[1 \\
.76]^{\mathrm{NS}}\end{array}$ & $\begin{array}{c}0.010(0.005)[1 \\
.89]^{\mathrm{NS}}\end{array}$ & $\begin{array}{c}0.004(0.002)[2 \\
.40]^{*}\end{array}$ & $\begin{array}{c}0.003(0.008)[0 \\
.36]^{\mathrm{NS}}\end{array}$ \\
\hline $\mathbf{E C T}_{\mathbf{t}-1}$ & $\begin{array}{c}- \\
2.713(0.267)[1 \\
0.2]^{* * *}\end{array}$ & $\begin{array}{c}- \\
1.826(0.611)[2 \\
.99]^{* *}\end{array}$ & $\begin{array}{c}1.896(0.169)[1 \\
1.2]^{* * *}\end{array}$ & $\begin{array}{c}- \\
1.760(0.159)[1 \\
1.1]^{* * *}\end{array}$ & $\begin{array}{c}- \\
1.661(0.145)[1 \\
1.5]^{* * *}\end{array}$ & $\begin{array}{c}- \\
1.920(0.077)[2 \\
4.9]^{* * *}\end{array}$ \\
\hline $\mathbf{R}^{2}$ & 0.968 & 0.978 & 0.888 & 0.965 & 0.977 & 0.956 \\
\hline F-stat & $\begin{array}{c}1663.6\{8.1 \mathrm{E}- \\
7\}^{* * *}\end{array}$ & $\begin{array}{c}11.14\{0.015\}^{*} \\
*\end{array}$ & $\begin{array}{c}39.96\{0.001\}^{*} \\
* *\end{array}$ & $\begin{array}{c}787.27\{3.6 \mathrm{E}- \\
6\} * * *\end{array}$ & $\begin{array}{c}5780.5\{6.7 \mathrm{E}- \\
8\}^{* * *}\end{array}$ & $\begin{array}{c}3201.7\{2.2 \mathrm{E}- \\
7\}^{* * *}\end{array}$ \\
\hline $\begin{array}{l}\text { Autoc } \\
\text { cr. }\end{array}$ & $3.91\{0.14\}^{\mathrm{NS}}$ & $0.011\{0.92\}$ & $0.33\{0.61\}^{\mathrm{NS}}$ & $0.38\{0.58\}^{\mathrm{NS}}$ & $0.088\{0.79\}^{\mathrm{NS}}$ & $0.27\{0.64\}^{\mathrm{NS}}$ \\
\hline $\begin{array}{l}\text { Arch } \\
\text { effect }\end{array}$ & $1.82\{0.18\}^{\mathrm{NS}}$ & $0.067\{0.80\}^{\mathrm{NS}}$ & $0.05\{0.83\}^{\mathrm{NS}}$ & $0.56\{0.45\}^{\mathrm{NS}}$ & $0.69\{0.41\}^{\mathrm{NS}}$ & $0.14\{0.71\}^{\mathrm{NS}}$ \\
\hline $\begin{array}{l}\text { Heter } \\
\text { osc. } \\
\text { test }\end{array}$ & $15.6\{0.48\}^{\mathrm{NS}}$ & $20.90\{0.18\}^{\mathrm{NS}}$ & $17.8\{0.34\}^{\mathrm{NS}}$ & $9.88\{0.87\}^{\mathrm{NS}}$ & $15.3\{0.50\}^{\mathrm{NS}}$ & $19.7\{0.23\}^{\mathrm{NS}}$ \\
\hline $\begin{array}{c}\text { Norm } \\
\text { ality } \\
\text { tst }\end{array}$ & $3.59\{0.17\}^{\mathrm{NS}}$ & $5.25\{0.07\}^{*}$ & $1.74\{0.42\}^{\mathrm{NS}}$ & $0.41\{0.81\}^{\mathrm{NS}}$ & $7.97\{0.02\}^{* *}$ & $3.04\{0.22\}^{\mathrm{NS}}$ \\
\hline $\begin{array}{l}\text { CUSU } \\
\text { M test }\end{array}$ & $-0.06\{0.96\}^{\mathrm{NS}}$ & $1.14\{0.31\}^{\mathrm{NS}}$ & $-2.06\{0.13\}^{\mathrm{NS}}$ & $-0.77\{0.50\}^{\mathrm{NS}}$ & $1.14\{0.31\}^{\mathrm{NS}}$ & $-1.56\{0.22\}^{\mathrm{NS}}$ \\
\hline
\end{tabular}

\subsection{Farmers' Yield Response for the Root and Tuber Crops}

\subsubsection{Long-run yield response}

A perusal of Table 6 shows that, price and non-price factors in the long-run that influenced farmers' decision on the current yield adjustments for yam, cassava and potatoes were lagged yam price, lagged cassava price, lagged potatoes price, lagged cassava yield risk, lagged yam and potatoes price risks; lagged yam yield risk, lagged cassava yield risk, lagged potatoes yield risk, 
lagged yam price risk, lagged potatoes area and lagged cassava yield; and, lagged potatoes price, lagged yam and cassava yields, lagged yam price risk, lagged yam and cassava areas, lagged yam yield, lagged cassava yield and lagged potatoes yield, respectively, as evidenced by their respective estimated coefficients which were different from zero at 10 percent significant level.

The price and non-price factors that encouraged farmers' to increase their current yam yield were lagged yam price and lagged potatoes price risk while those factors that makes farmers to relapse were lagged cassava and potatoes prices, lagged cassava yield and lagged yam price risk. The implication of a percent increase in the lagged yam price and lagged potatoes price risk will encourage the farmers to increase their current yam supply by 0.33 percent and 0.10 percent respectively; while a percent increase in the lagged cassava and potatoes prices, lagged cassava yield and lagged yam price risk will force the farmers to reduce their current yam supply by 0.37 percent, 0.17 percent, 0.03 percent and 0.05 percent respectively.

The results showed that, lagged yam yield risk, lagged potatoes price risk, lagged potatoes area and lagged cassava yield motivate farmers to increase their current yield of cassava while lagged cassava yield risk and lagged yam price risk dissuade them from increasing the current supply of cassava. The implication of a percent increase in the lagged yam yield risk, lagged potatoes price risk, lagged potatoes area and lagged cassava yield will make the farmers to increase the current cassava supply by 0.02 percent, 0.04 percent, 0.05 percent and 0.40 percent respectively; while a percent increase in the lagged cassava yield risk and lagged yam price risk will decrease the current cassava supply by 0.028 percent and 0.033 percent respectively.

The factors that encouraged increase and decrease in the current potatoes yield were lagged potatoes price, lagged potatoes yield, lagged cassava area and yield and lagged yam yield risk; and, lagged cassava yield, lagged yam price risk, lagged yam area and yield respectively. The elasticity implication of a percent increase in the lagged potatoes price, lagged potatoes yield, lagged cassava area, lagged cassava yield and lagged yam yield risk will make the farmers to increase their current supply of potatoes by 0.28 percent, 0.44 percent, 1.78 percent, 1.77 percent and 0.04 percent respectively; while a percent increase in the lagged cassava yield, lagged yam price risk, lagged yam area and yield will force them to reduce their current potatoes supply by 0.06 percent, 0.08 percent, 2.70 percent and 2.23 percent respectively.

Therefore, it is inferred that in the long-run, cassava and potatoes crops compete with yam crop as their price factors had negative influence on the farmers' decision on the current yam supply. The contributions of the price and non-price factors to the current yam, cassava and potatoes supplies were 86.3 percent, 97.4 percent and 92.9 percent respectively as shown by their respective coefficient of multiple determinations.

\subsubsection{Short-Run Yield Response}

A perusal of Table 7 showed short-run dynamics of the yield responses for yam, cassava and potatoes to have long-run equilibrium as indicated by their respective attractor coefficients which were different from zero at 10 percent degree of freedom. The attractor coefficients of 1.76, 1.661 and 1.92 for yam, cassava and potatoes supply responses implies that the current yield in the shortrun responds to shocks from any of the short-run parameters by correcting their previous deviation 
from the equilibrium at the speed of 176 percent, 166.1 percent and 192 percent respectively. The approximate time taken annual for the yield in the short-run to adjust the supply of yam, cassava and potatoes to establish a long-run equilibrium would be 21.12, 19.93 and 23.04 months respectively. However, the degree of adjustment of the current supply in all the short-runs was very low, that is, the degree of integration of the current supply with its predictor variables was very low as evidenced from the long length of time required for the short-run dynamics to establish a long-run equilibrium.

With the exception of the lagged potatoes yield risk, lagged potatoes yield and lagged cassava yield, all the remaining predictor variables had short-run causal effect on the current yam supply decision of the farmers. The predictor parameters, viz, lagged cassava and potatoes prices, lagged cassava and yam yield risks, lagged yam price risk, lagged potatoes and cassava areas and lagged yam yield have negative influence on the current yam supply decisions while lagged yam price, lagged potatoes and cassava price risks and lagged yam area positively influenced farmers' decision on the current yam supply. The resultant implication of a percent increase in those parameters that negatively influenced farmers' decision on the current supply of yam will be decrease in the current supply of yam while those with positive influence will encourage them to increase the current supply of yam in the country. Therefore, it can be inferred that the farmers in the short-run are likely to be caught in the cob-web cycle of price as a result of supply shift to the competing crops.

A cursory review of the study showed that the decision of the farmers on the current cassava supply was virtually influenced by the non-price factors as almost all the estimated price factors (except lagged yam price) were found not to be different from zero at 10 percent probability level. The factors which positively influenced the decision of the farmers on the current supply of cassava were lagged yam price, lagged yam and potatoes yield risks, lagged cassava and potatoes price risks and lagged potatoes area while predictor variables viz. lagged cassava yield risk, lagged yam price risk, lagged yam and cassava areas negatively influenced farmers' decision on the current supply of cassava. The elasticity implication of a percent increase in those predictors with positive influence will make the farmers to increase their current supply of cassava in the country while those variables with negative influence will make the farmers to relapse the current cassava supply in the country. Therefore, it can be inferred that yam is a competing crop with cassava as farmers will seize any slight opportunity of remunerative price to shift their supply from cassava to yam crop in order to avert price crash as a result of glut. However, this will not augur well if there is no mechanism to handle the glut that will likely arise in the current period as the farmers will be caught in the web of convergent cob-web cycle.

Furthermore, predictor coefficients, viz, lagged potatoes price, lagged yam yield risk, lagged cassava price risk, lagged potatoes area and yield, lagged cassava area and yield were found to exert positive influences on the farmers decision on the current potatoes supply while lagged cassava yield risk, lagged yam price risk, lagged yam area and yield exerted negative influences on the farmers' decision on the current potatoes supply. Based on these outcomes, it can be inferred that the non-price factors of the competing crop (yam) caused a paradigm shift in of supply potatoes to yam. 


\subsection{Diagnostic Test}

The results in Table 8 showed that the residuals of the short-run acreage and yield response models for each of the selected crops have no autocorrelation and arch effects as indicated by their respective Langrage multiplier and Breusch-Pagan tests respectively, which were not different from zero at 10 percent probability level. However, with the exception of cassava acreage and yield response models the errors of the supply response of the remaining selected crops were normally distributed as evidenced by their respective Chi2 statistics which were not different from zero at 10 percent degree of freedom. The test of multicollinearity showed no evidence of covariance between the predictor variables as indicated by the VIF values which were less than 10 for each of the explanatory variables. In addition, the F-statistics for both the long-run and shortrun acreage and yield models for each of the selected crops were different from zero at 10 percent probability level, an indication that the estimated parameter coefficients in the models were different from zero at 10 percent risk level, thus, implying that the variables have influence on the farmers decision on the acreage and yield adjustments. The results also showed no structural break in the equation as indicated by their CUSUM test statistics which were not different from zero at 10 percent probability level.

Table 8: Diagnostic test results for the short-run dynamic model

\begin{tabular}{|c|c|c|c|c|c|c|}
\hline Variables & $\Delta A Y M_{t}$ & $\Delta A C_{t}$ & $\Delta A P T_{t}$ & $\Delta Y Y M_{t}$ & $\Delta Y C_{t}$ & $\Delta Y P T_{t}$ \\
\hline $\ln A Y M_{t-1}$ & 1.05 & 1.12 & 1.11 & 1.15 & 1.08 & 1.05 \\
\hline $\ln \mathrm{AC}_{\mathrm{t}-1}$ & 4.48 & 2.76 & 2.02 & 2.63 & 2.37 & 2.28 \\
\hline $\ln \mathbf{A P T}_{\mathrm{t}-1}$ & 2.07 & 8.48 & 9.17 & 1.02 & 8.22 & 8.04 \\
\hline $\ln Y_{M P} P_{t-1}$ & 2.24 & 5.73 & 3.24 & 7.21 & 4.90 & 3.99 \\
\hline $\operatorname{lnCP} P_{t-1}$ & 2.64 & 6.28 & 3.23 & 9.07 & 5.17 & 3.88 \\
\hline $\operatorname{lnPTP}_{t-1}$ & 4.23 & 3.83 & 3.04 & 3.15 & 3.59 & 3.09 \\
\hline $\ln ^{\prime} \mathbf{M P R}_{\mathrm{t}-1}$ & 7.63 & 4.45 & 4.45 & 5.03 & 5.13 & 5.13 \\
\hline $\operatorname{lnCPR} R_{t-1}$ & 2.73 & 3.14 & 2.97 & 3.02 & 3.43 & 2.81 \\
\hline $\operatorname{lnPTPR}_{\mathrm{t}-1}$ & 1.36 & 7.82 & 6.29 & 9.75 & 7.86 & 6.32 \\
\hline $\ln Y Y_{\mathbf{t}-1}$ & 1.19 & 1.33 & 1.12 & 1.07 & 1.31 & 1.07 \\
\hline $\ln Y C_{t-1}$ & 2.32 & 1.75 & 1.65 & 1.76 & 1.75 & 1.75 \\
\hline $\ln \mathbf{Y P T}_{\mathrm{t}-1}$ & 4.75 & 4.44 & 4.16 & 3.98 & 4.30 & 4.21 \\
\hline $\operatorname{lnYMYR_{t-1}}$ & 2.61 & 9.44 & 6.27 & 9.11 & 6.67 & 5.96 \\
\hline $\operatorname{lnCYR}_{\mathrm{t}-1}$ & 1.13 & 6.77 & 5.29 & 5.97 & 5.58 & 5.21 \\
\hline $\operatorname{lnPTYR}_{\mathrm{t}-1}$ & 4.50 & 4.13 & 3.01 & 2.91 & 3.16 & 2.61 \\
\hline $\mathbf{E C T}_{\mathrm{t}-1}$ & 1.20 & 3.61 & 2.71 & 4.35 & 2.45 & 1.82 \\
\hline
\end{tabular}

\subsection{Time Required for the Price Effect to Materialize in the Short-Run and Long-Run}

A perusal of Table 9 showed the lagged price predictors for almost all the crops both at the longrun and short-run across the current acreage and supply decisions to be positive except for yam acreage in both periods and cassava supply in the short-run. However, it is worth to note that the negative supply response is not an uncommon feature on supply response as indicated in many earlier studies. Wogayehu and Tewodros (2017) in their study found a negative price coefficient in the short-run yield response of haricot bean produced in the Boricha district of southern Ethiopia. Also, negative price coefficient was found in the short-run results of maize supply response study conducted by Ayelwa (2015) in Ethiopia. Jain (2002) reported negative price coefficients in five principal crops grown in Rajasthan state of India. Cumming (1975) also 
reported uniform price response for all the wheat areas at the state level, but negative price coefficients in nearly half of the hundred wheat growing districts in India. Negative price response in six cases out of the fourteen cases in groundnut crop was reported in the study of Jhala (1979). Negative price coefficients in nearly six-gram growing districts of Punjab were found in the study of Sud and Kahlon (1969). In addition, these kinds of conflicting estimates were reported in the studies of Krishna (1963); Krishna and Rao (1967); Bhowmick and Goswami (1998) and Karunakaran N (2014 and 2016).

The number of year(s) required for the price effect to materialize depends on the technological and institutional constraints faced by the farmers for a particular crop. The higher the constraints, the more is the time needed for the adjustment. It was observed that all the crops across the acreage and yield in the long-run will take very small time for adjustment. In the short-run with respect to area, crops like yam and cassava required little time for adjustment while potatoes required large time for adjustment. In respect of yield response in the short-run, crop, viz, potatoes required very small time for adjustment while cassava required large time for adjustment. The smaller the time for adjustment, the more effective is the price policy instruments in bringing about desired change in the supply of a crop. Still on the yield response, the number of years required for price effect to materialize for yam was indeterminate.

The adjustment coefficients of the acreage and yield responses both in the short-run and long-run were less than one, implying that the adjustments go on and gives rise to lags which will be distributed over time. Furthermore, almost all the adjustments coefficients were quite large, indicating rapid adjustments of area and yield under all the selected crops by the farmers.

Table 9: Time required for the price effects to materialize

\begin{tabular}{|c|c|c|c|c|c|c|}
\hline \multirow{2}{*}{ Crops } & Price elasticity & Adjustment coefficient & Time required (Year) \\
\cline { 2 - 7 } & Long-run & Short-run & Long-run & Short-run & Long-run & Short-run \\
\hline \multicolumn{7}{|c|}{ Acreage response } \\
\hline Yam & -0.589 & -1.180 & 0.823 & 0.755 & 1.73 & 2.13 \\
\hline Cassava & 0.071 & 0.150 & 0.538 & 0.891 & 3.89 & 1.35 \\
\hline Potatoes & 0.001 & 0.233 & 0.3217 & 0.0597 & 7.72 & 48.67 \\
\hline \multicolumn{7}{|c|}{ Yield response } \\
\hline Yam & 0.333 & 0.629 & -0.5793 & -0.416 & - & - \\
\hline Cassava & 0.0625 & -0.0365 & 0.400 & 0.124 & 5.86 & 22.68 \\
\hline Potatoes & 0.278 & 0.216 & 0.444 & 0.620 & 5.11 & 3.10 \\
\hline Source: Authors' computation, 2018 \\
\hline
\end{tabular}

\section{Conclusions and Recommendations}

The study empirically examined the growth pattern, acreage and supply responses of root and tuber crop farmers in Nigeria. The findings showed that the annual production growth rates for all the crops were positive across all the reform eras inclusive the overall period. However, the annual growth rate in the area rather than yield increase accounted for the annual positive production growth rate recorded across all the periods. In addition, comparative overview showed the SAP era to have higher annual positive production growth rate than the other reform periods. Findings further showed that area effect was the major source of changes in the output of all the selected 
crops across the reform periods and the overall period. The instabilities in the productions of all these crops were low across the reform eras and the overall periods. In addition, it was observed that the farmers' acreage and yield decisions for all the selected crops were influenced by the price and non-price factors. Generally, the farmers respond to price incentives in reallocating their areas and yield increase for all the selected crops. It was observed that the acreage and yield for all the selected crops had long-run association with the price and non-price factors; likewise, they established long-run equilibrium. Based on these findings, it can be inferred that the increase in the area was responsible for the paradigm shift in the production of the selected crops and not the yield which is required for sustainable agriculture due to pressure on the shrinking arable land available in the country. In addition, there is still great potential to increase production of root and tuber crops in the country through the improvement of price and non-price inputs. Therefore, price forecast mechanism should be put in place in order to protect the farmers from the problems of cob-web cycle.

\section{References}

[1] Ayalew B (2015), "Supply response of maize in Ethiopia: Cointegeration and Vector Error Correction Approach", Trends in Agricultural Economics, 8 (1): 13-20.

[2] Bhowmick B C and Goswami J (1998), "Supply response of some important crops in Assam: An inter-district analysis", Agricultural Situation in India, 55 (6): 349-356.

[3] Blay J K, Maiadua S U and Sadiq M S (2015), "Horizontal market integration and price transmission between maize, sorghum and millet in Dawanau market, Kano State, Nigeria: Evidence from non-linear vector error correction model", Global Journal of Agricultural Economics, Extension and Rural Development, 3 (10): 330-337.

[4] Cummings J T (1975), "The supply responsiveness of Indian farmers in the post-independence periods-major cereals and cash crops", Indian Journal of Agricultural Economics, 30 (1): 25-40.

[5] Debnath P, Singh R, Feroze S M and Sarkar A (2015), "Study on growth and instability of sesame in north-eastern hill region of India", Economic Affairs, 60 (2): 193-196

[6] Dhakre D S and Sharma A (2009), "Growth and instability analysis of ginger production in NorthEast Region”, Agricultural Situation in India, 66 (8): 463-466.

[7] Jain P K (2002), "Growth and instability of agriculture in Rajasthan: An economic analysis", Unpublished $\mathrm{PhD}$ thesis submitted to the Department of Agricultural Economics, RAU, Bikaner, India

[8] Jhala M L (1979), "Farmers response to economic incentive: An analysis of inter-regional groundnut supply response in India", Indian Journal of Agricultural Economics, 34 (1): 55-67

[9] Karunakaran N (2014), "Determinants of changes in cropping pattern in Kerala", Journal of Rural Development, 33 (4): 367-376.

[10] Karunakaran N (2016), "Rubber cultivation in Kerala: Determinants and growth", Agricultural Situation in India, 73 (5): 29-34.

[11] Krishna J and Rao M S (1967), "Dynamics of acreage allocation in U P: A study of supply response", Indian Journal of Agricultural Economics, 22 (1): 37-52.

[12] Krishna R (1963), "Farm supply response in India-Pakistan: A case study of the Punjab Region", Economics Journal, 73 (291): 477-487

[13] Maddala G S and Kim I W (1998), Unit Roots Co integration and Structural Change, Cambridge University Press, New York

[14] Maddala G S and Lahiri K (2013), Introduction to Econometrics, Fourth Edition, Published by John Wiley and Sons, Incorporation. 
[15] Sadiq M S, Singh I P and Karunakaran N (2017), "Supply response of cereal crop farmers' to price and non-price factors in Rajasthan State of India", Journal of Agricultural Economics and Rural Development, 3 (2): 203-210.

[16] Sadiq M S, Singh I P, Suleiman, A, Umar, S M, Grema I J, Usman B I, Isah M A and Lawal A T (2016), "Extent, Pattern and Degree of Integration among Some Selected Cocoa Markets in West Africa: An Innovative Information Delivery System”,Journal of Progressive Agriculture, (2): 2239

[17] Sandeep M V, Thakare S S and Ulemale D H (2016), "Decomposition analysis and acreage response of pigeon-pea in western Vidarbha", Indian Journal of Agricultural Research, 50 (5): 461465.

[18] Singh I P, Sadiq M S, Umar S M, Grema I J, Usman B I and Isah M A (2016), "Cointegration and causality: an application to GDP and major sectors of Nigeria”, International Journal of Innovative Research and Review, 4 (2): 40-53.

[19] Sud L and Kahlon A S (1969), "Estimation of acreage response to price of selected crops in Punjab State", Indian Journal of Agricultural Economics, 34 (3): 46-49.

[20] Wogayehu A and Tewodros T (2017), "Supply response of haricot bean: The case of Boricha District, Southern Ethiopia", Journal of Agriculture and Crops, 3 (4): 29-35.

\footnotetext{
*Corresponding author.

E-mail address: narankarun @gmail.com
} 